\title{
Productivity and profitability analysis of Nationalized Commercial Banks (NCBs) in Bangladesh
}

\author{
Md. Imtiaj Rahman ${ }^{1}$, Debasish Adhikary ${ }^{2}$, Salahuddin Yousuf ${ }^{2}$ \\ ${ }^{1}$ School of Accounting and Finance, Charles Sturt University, Melbourne, Australia \\ ${ }^{2}$ Business Administration Discipline, Khulna University, Khulna, Bangladesh
}

Email address:

Imtiaj.csu@gmail.com (M. I. Rahman), debasish06me@gmail.com (D. Adhikary), yousufsalahuddinbd@gmail.com (S. Yousuf)

\section{To cite this article:}

Md. Imtiaj Rahman, Debasish Adhikary, Salahuddin Yousuf. Productivity and Profitability Analysis of Nationalized Commercial Banks (NCBs) in Bangladesh. International Journal of Economics, Finance and Management Sciences. Vol. 2, No. 2, 2014, pp. 197-205. doi: $10.11648 /$ j.jjefm.20140202.22

\begin{abstract}
Banks, the leading financial institutions, are the major contributors in the economic \& financial development of Bangladesh. Performance of banking sector in Bangladesh has invited a lot of comments in recent years. It is no doubt an important problem. Profitability, productivity and associated risks to these two components are the major criteria for evaluating the performance of banks. In this study, it has been tried to find out the performance of NCBs within a very short period (2008 to 2012). There are four nationalized commercialized banks in Bangladesh. For the convenient of this research study three banks have been taken. The study relies on secondary sources of data. The tables in the study highlights movements of banking variables as reflected in the branch expansion, deposit mobilization, deployment of credit, operational efficiency and relative risk measures. The results so far achieved through ratio analysis are not very encouraging. In the light of this finding, it can be realized that the confidence of the general public, who wants to rely on these NCBs, in the soundness of the banking system, remains unimpaired and the financial strength of the banks gets increased. Also some recommendations are put forward to move in an effective pace with regard to time covering the whole banking system, emphasize more on achieving core objectives.
\end{abstract}

Keywords: Profitability, Productivity, Performance, Nationalized, Commercialized, Banks

\section{Introduction}

\subsection{Background of the Study}

Finance is the life blood of economic development in any country. It helps in capital formation and capital accumulation, both of which are essential for the growth of an economy. For ensuring capital formation, the financial resources of a country need to be mobilized in such a way that they are put in productive channels. However, to undertake massive capital formation there is a paucity of a sound financial infrastructure in most of the under developed economies. Bangladesh is not the exception amongst those under developed countries. The Nationalized Commercial Banks (NCBs) have been playing a vital role in the economy of Bangladesh since its invention in 1971. In a developing country like Bangladesh, the banking sector has been assigned an important role for achieving certain socio-economic objectives. The commercial banking system dominates Bangladesh's financial sector.
Bangladesh Bank is the Central Bank of Bangladesh and the chief regulatory authority in the sector. The banking system is composed of four state-owned commercial banks, five specialized banks, thirty eight private commercial banks, one land development bank and nine foreign commercial banks. The Nobel-prize winning Grameen Bank is a specialized micro-finance institution, which revolutionized the concept of micro-credit and contributed greatly towards poverty reduction and the empowerment of women in Bangladesh.

After the independence, banking industry in Bangladesh started its journey with 6 nationalized commercialized banks, 2 State owned specialized banks and 3 Foreign Banks. In the 1980s banking industry achieved significant expansion with the entrance of private banks.

\subsection{Statement of the Problem}

For past several years, the Nationalized Commercial banks have been facing a ups and downs in the performance as per productivity and profitability. Therefore, 
it is necessary to explore the performance of these banks and examine how they can achieve the targeted aims and operational expertise.

\subsection{Objective}

1. To examine Productivity and profitability analysis of Nationalized Commercial Banks (NCBs) in Bangladesh.

2. To evaluate the performance of the nationalized commercial banks.

3. To examine factors contributing to the low or high performance of the banks.

4. To offer suggestions for achieving the goals of financial discipline with operational efficiency of the banking sector.

\subsection{Methodology}

\subsubsection{Source of Data and Data Collection}

To complete the study in the light of research objectives, information both from the primary and secondary sources are considered necessary. However, first, in order to build up theoretical premise, standard textbooks, reference books, domestic journals and other related literature have been consulted. In the next stage, the related secondary information has been collected from annual reports and other official records of the banks.

\subsubsection{Sample}

There are four nationalized commercialized banks in Bangladesh. For the convenient of this research study three banks have been taken. Activities of these three banks will cover the major portion of this study.

Name of the sample banks:

1. Sonali bank.

2. Agrani bank

3. Janata bank

\subsubsection{Reference Period}

This study has covered the period from 2008 to 2012.

\subsubsection{Data Analysis}

The collected information have than been tabulated, analyzed and the findings thereof has laid the basis of research report. Data processing and analysis have been done both manually and by using computer. Tabular method, ratio analysis and suitable statistical tools \& techniques have been used operationally the research where required.

\subsubsection{Coverage of the Study}

At present four nationalized commercial banks with over 3500 branches are operating throughout the country. Out of these four nationalized banks three larger were being taken into consideration for research purpose. Performance of these banks within this very short period has been evaluated with the help of some ratios in the light of profitability and productivity.

\subsection{Limitation and Scopes}

Performance evaluation is very important for every financial institution for finding out their efficiency in different sectors. The study has been conducted only on the three out of four nationalized commercial banks which will give a clear cut picture regarding their performance.

The study cannot overlook these limitations

1. Only five years time is not enough to complete such a study regarding performance, in a lucid manner.

2. Bank management was not that much willing to provide the required data.

3. Some of the ratios were not reproduced in a full-fledged manner because of annual reports of these banks, which were inconsistent and incomplete in some aspect.

4. Because of shortage of time the study is done by covering only major ratios. Though some other ratios are even responsible for the performance of the banks.

\section{Literature Review}

N S Toor (1994) has said that the profits are needed by the banks for a number of reasons, such as banks are basically commercial organizations and in order to ensure that the depositors and lenders have faith and confidence on themselves i.e., to meet their expenses and for further growth, they must earn income and profits. He has also pointed out that, immediately after the nationalization of banks, the profitability in banks ceased to be an important parameter for measuring their performance and instead, their developmental and social role got precedence over the profits and profitability.

Birla Institute of Scientific Research (1981) concluded that the growth in deposit in the post nationalization period could not be entirely attributed to the nationalization of major banks, but among others, inflationary trends in the economy was largely responsible for this. After nationalization, though the nationalized banks vastly expanded their network of branches, but they could not achieve the objective of greater participation in the rural development. Moreover, the study pointed out that after nationalization of major commercial banks, the customer services had been deteriorated.

Deshpande (1981) has observed that not only the external factors (like increase in CRR and SLR, changes in the interest rate structure, fixing the targets for priority sector financing, etc.) but also the internal factors (such as efficiency in management of funds and manpower, appropriate linkage of wage cost with business of bank, organizational strength and weaknesses, planning and system approach etc.) were equally responsible for the deterioration in the profitability and productivity of the commercial banking system.

Varda and Singh (1987) has said that heavy competition for deposits from non banking financial institutions (which 
we call financial disintermediation) was also expected to cast negative impact on the banks' profitability.

Fraser (1990) has said that the performance of a commercial banking organization is obviously better if its profits are higher and the risk is lower. In practice, high profit generally necessitates accepting greater amount of risk. There are many dimensions of risks encompassing credit, interest rate, liquidity, etc. the net effects of these types of risk are reflected in the number of banks' failure which has become problems and subject to increased supervision by the regulatory authorities. He has pointed out that major factors affecting performance. These are advances in technology, more sophisticated customers, securitization, and deregulation.

Vitta (1991) has said that measuring bank efficiency is difficult because there is no satisfactory definition of bank output. Neither the number of accounts nor total assets, total loans and total deposits provide a good index of output Moreover, the value added of banks- given by their labor costs and profits measures both the output and the cost of banking.

$\mathrm{He}$ has also mentioned that banks in developing countries operate with relatively widespread. Those are caused by government policies and regulations and by operating inefficiencies. For instances, a wedge between loan and deposit rates, at least for the non- privileged customers of banks, is created by the imposition of onerous reserve requirements and other forms of bank taxation, the operation of directed credit programs and a high level of inflation. In addition, high operating costs, large loan losses and large profits from uncompetitive behavior are also translated into wide bank spread.

He has further stated that the study of bank performance and efficiency would present few difficulties if all banks bad the same capital structure, offered the same mix of services, followed identical accounting practices, were equally affected by inflation and operated under the same regulatory restrictions. Under these circumstances, a simple comparison of interest margins, cost ratios of return would provide a clear indication of relative efficiency even in the absence of a satisfactory definition of bank output.

Rose P. (1996) has pointed out that there are two key dimensions of bank performance profitability and exposure to risks. Profitability is clearly the more important, because satisfactory profits preserve the bank's capital, providing it with a base for further survival and growth.

Baher (1989) has critically evaluated the performance of NCBs and other commercial banks in terms of social justice and other indicators. He found that social banking and profitability more in opposite direction.

Sing (1993) in his paper has given an overall view about profit planning in banks and stressed on the awareness of breakeven point to improve the profitability. He conducted that the level of profitability would largely depend on cost consciousness, overall monitoring management, quality of asset management, level of non-fund business and the customer services.
Mishra (1992), in his paper has analyzed the profitability of scheduled CBs in India taking into account interest and non-interest income and interest expenditure, manpower expenses and other expenses. He concluded that that the growing pre-emption funds in the form of SLR, CRR, faster increase of expenses as compared to income, advances and total investment than interest income and few more have contributed to the declining profitability of CBs.

Varda, V.S. and Sing, S.P. (1982) have studied the issues of bank profitability under the Indian conditions and develop a simple framework to analyze the factors influencing the profitability of CBs. They are of the view that any emphasis on the increase of the volume of business and proper management of burden would definitely result in enhancing the profitability of CBs. They concluded that, the keys to profitability of CBs in Bangladesh are high volume of business (in total, per employee) and not the expenses (per branch and per person) which are popularly practiced.

\section{Concepts and Definitions}

\section{Sonali Bank}

The largest nationalized commercial bank of the country, Sonali bank, was found in 1972 with a paid-up capital of Tk. 20 million only. Meanwhile, both paid-up capital and reserves of the bank have increased impressively. These two stood at Tk.3272 million and 2136 million respectively as at the close of 2011. Total asset of the bank stood at Tk.253872 million. The bank having the largest network of 1291 branches had a deposit and credit base of Tk.210.45 billion and Tk.141.916 billion respectively. Sonali bank had 25753 employees. The bank in addition to its normal day-to-day banking, also conducts treasury functions on behalf of the Bangladesh Bank where it does not have any office.

\section{Janata Bank}

The second largest nationalized commercial Bank-Janata Bank-having a country wide network of 900 branches was established under the 'Bangladesh Banks (Nationalization) Order-1972' with a paid-up capital of Tk.15 million only. Its paid-up-capital and reserves have increased to Tk.2594 million and tk.539 million respectively as at the year-end, 2011. Total assets of the bank stood at Tk.151862 million as of end-December, 2011.it had a deposit and credit base of Tk.124122 million and Tk.89862 million respectively as on end December, 2011.

\section{Agrani Bank}

Established under the same Nationalization Order, Agrani Bank started its operation in 1972 with a paid-up-capital of Tk.10 million only. Equally strong like other nationalized banks, more particularly Janata Bank, this bank had a paid-up capital and reserves of Tk.2484 million and Tk.822 million only as on end-December, 2011. 
Its total assets stood at Tk.131068 million. The bank had a deposit and credit base of Tk.106713 million and Tk.80016 million respectively as on the same date. Number of branches and employees including officers stood at 903 and 13058 respectively.

\section{Profitability and Measures of Profitability}

Profitability is the profit earning capacity of a product, plant, process or an undertaking. Profitability is the yardstick for judging the efficiency of an undertaking. Profit and profitability play the same role in business as 'blood' and 'pulse' in human body. Without adequate blood and ability to generate blood, it may not be possible on the part of human being to survive. Like this, without profit and ability to earn sufficient profit, it is difficult to survive on the part of any business. Same thing can be true in the case of banking business. Profit and profitability is the backbone of a banking business. Profit maximization is the aim of every banking business. Hence, profit-earning capacity indicates the efficiency. The greater the volume of profit, the more efficient the bank is. The word profitability is composed of two words: 'profit' and 'ability'. 'Ability' refers to the earning capacity of a bank to earn the profit. So, profitability may be defined as the ability of a given investment to earn a return from its use. Profitability of a concern indicates the financial stability and greater possibility of profit earning. The height of profitability depends on the ability of management to deal intelligently and effectively to tide over risks and uncertainty through shifting them or hedging benefits. Profitability of different concerns varies as it depends upon types of business, risk involved, policy decision, etc. Profit refers to the absolute quantum of profits and is not always the sole index of judging efficiency of an organization. Profit does not reveal the reason, how it takes place and relationship of one figure with another one. Hence measurement of profitability to ascertain the real efficiency and performance of an organization is of utmost importance. Key profitability ratios used in this study are:

\section{Interest Yield}

The Interest Yield measures how large a spread between interest revenues and interest costs, management has been able to achieve by close control over the bank's earning assets and the pursuit of the cheapest source of funding.

Interest Yield is a summery measure of a bank's total interest income against all income producing assets. Interest Yield is being expressed in terms of a ratio between total interest income and earning assets of a bank.

Interest Yield $=$ Total Interest Income/ Earning Assets.

Here, Earning Assets = Net Advances + Bills Purchase + Investment + Money at Call and Short notice

\section{Return on Asset (ROA)}

ROA is primarily an indicator of managerial efficiency. It indicates how the management of the bank is capable of converting the institution's asset into net earnings. ROA is expressed as a ratio of net income (net profit after tax) and total assets of a bank.

$\mathrm{ROA}=($ Net income or net profit $) /$ Total assets.

Here net income means both interest and non-interest income less taxes and provision.

\section{Return on Equity (ROE)}

ROE also provides a direct measure of the returns flowing to the bank's shareholders. ROE is the ratio of net income and shareholder's fund or equity capital.

$\mathrm{ROE}=$ Net income/Equity capital.

Equity capital of a bank comprises paid up capital and reserves of the banks.

It may, however, be determined by the DuPont system as follows

ROE $=$ Profit Margin $*$ Degree of Asset Utilization * Equity Multiplier

(a) Profit Margin = Net profit after tax/Total income.

It reflects the effectiveness of expense management and service pricing policies.

(b) Degree of Asset Utilization = Total Income/Equity capital.

It reflects the portfolio management policies (especially the mix and yield on the bank's assets.)

(c) Equity Multiplier $=$ Total Assets/Equity Capital.

It reflects leverage or financing policies-the force chosen to fund the bank (debt and equity mix)

\section{Return on Risk Assets}

Return on risk assets measures percentage (\%) of net profit against all booked and contingent assets of the banks. It is also indicator of managerial efficiency of how the management of the bank is capable of converting the institution's risk assets into net earnings.

Return on Risk Assets $=($ Net income or net profit $) /$ Risk Assets.

In this context, management has considered Risk Assets and respective Earning Assets as the following way -

Risk Assets $=$ Earning Assets $+\mathrm{L} / \mathrm{Cs}+$ Guarantees and

Acceptances + Bills for Collections

Earning Assets = Net Advances + Bills Purchase + Investment + Money at Call and Short notice

\section{Earnings per Share}

This ratio provides a direct measure of the returns flowing to the bank's shareholders. It is being calculated as follows

EPS $=$ Net profit after tax / No. of common share issued

\section{Productivity and Measures of Productivity}

Productivity is defined as a ratio of total output and total input. There is no well definition of bank's productivity. But in this study income is considered as bank's output. Bank's input in this respect is manpower of the bank and 
number of branches of a bank. In this study the following productivity ratios are used to evaluate branch and employee performance.

Deposit-Capital Ratio = Total Deposit/ Equity Capital

It measures how much of equity capital is deploying to generate deposits

Credit-Deposit Ratio $=($ Net advances + Bills Purchase)/Total Deposit.

It measures the percentages (\%) of deposits deployed as advances to customers. A target number is usually 70-80\%.

Deposit per employee $=$ Total Deposit $/$ Total Employee

The ratio calculates the productivity of an individual employee.

Credit per employee $=$ Total advances $/$ Total Employee

It is also a productivity ratio that calculates the productivity of an individual employee.

Net income per branch $=$ Net income/No. of branches.

It measures how much a bank's branch is contributing in the performance of the bank.

Net income per employee $=$ Net income $/$ No. of employees.

The ratio calculates the productivity of an individual employee.

Deposit per branch $=$ Total deposit/No. of branches.

It shows how much each branch is generating the deposit which is liability on the part of a bank.

Earning base in assets = (Total assets-Non earning asset)/Total assets.

\section{Measures of Cost Efficiency}

Cost-efficiency ratios express the ability of the banks; how they are effectively allocating their total cost in different sectors, which in turn, contribute to the healthy economic framework of the banks. Here some of the cost-efficiency ratios are reflecting the performance of the NCBs

\section{Manpower Expenses to Total Expenses}

Manpower Expense to Total Expense = Manpower Expense/ Total Expense

It measures proportion of the bank's total expense that is expended to generate productivity through paying the employees. Manpower expense consists of salaries \& allowances plus MD's salary plus Directors fees. Total expense covers both the interest and non-interest expenses.

Salary per unit (Tk.100) of Deposit

Salary per unit of Deposit $=$ Salary \& Allowances/Deposit *100

\section{Analysis and Findings}

\subsection{Interest Yield}

Trends in IY have been shown in table. SB, AB and JB got their highest IY\% in 2009, 2008 and 2008 respectively. But they got their least IY\% in the same year, 2012. It appears from the table that the yearly interest yields of all the three NCBs are in the declining sequence. SB can be ranked first among the NCBs though in $2012 \mathrm{JB}$ accede the rate. Even the figure reflects this very clearly. It means that SB management has been able to efficiently control the bank's earning assets than the other two banks over the study period.

Table 1. Interest Yield.

\begin{tabular}{cccc}
\hline Year & \multicolumn{3}{c}{ Interest Yield (\%) } \\
& Sonali Bank & Agrani Bank & Janata Bank \\
\hline 2008 & 6.84 & 7.16 & 7.47 \\
2009 & 7.14 & 6.06 & 6.72 \\
2010 & 6.44 & 5.52 & 5.91 \\
2011 & 5.89 & 5.09 & 5.83 \\
2012 & 4.97 & 4.60 & 5.56 \\
\hline
\end{tabular}

Source: Annual reports of the sample banks

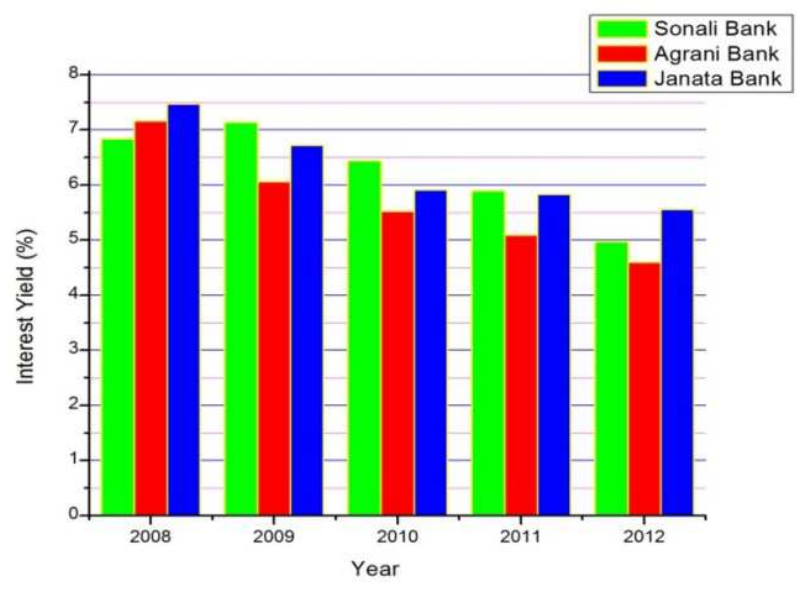

Figure 1. Interest Yield.

\subsection{Return on Assets (ROA)}

Table 2. Return on Assets (ROA).

\begin{tabular}{cccc}
\hline Year & \multicolumn{3}{c}{ Return on Assets (\%) } \\
& Sonali Bank & Agrani Bank & Janata Bank \\
\hline 2008 & .051 & .004 & .0224 \\
2009 & .057 & .004 & .0088 \\
2010 & .055 & .016 & .0087 \\
2011 & .032 & .001 & .0073 \\
2012 & .058 & .010 & .0087 \\
\hline
\end{tabular}

Source: Annual reports of the sample banks

The table shows that the year wise ROA had been fluctuated over the years from 2008 to 2012. It is observed that the asset of the bank, increase in the study period (from 2008 to 2012) at an increasing rate but relatively the banks were unable to generate more profit from the incremental asset. 


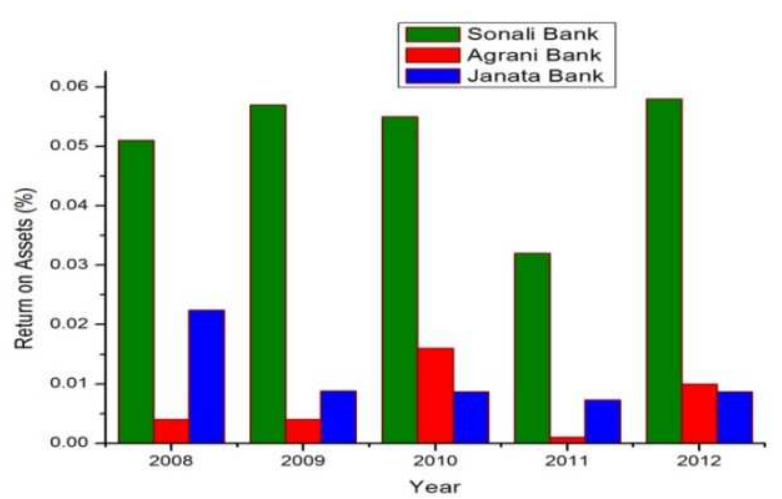

Figure 2. Return on Assets (ROA).

In 2011, SB got the lowest return on its assets within the study period; so as to the two other banks did in the same year. SB, AB and JB got their highest returns in 2012, 2010 and 2008 respectively. The table shows that the performance of banks in generating returns on their assets is not satisfactory.

\subsection{Return on Equity}

Table 3. Return on Equity (\%).

\begin{tabular}{cccc}
\hline \multirow{2}{*}{ Year } & \multicolumn{3}{c}{ Return on Equity (\%) } \\
& Sonali Bank & Agrani Bank & Janata Bank \\
\hline 2008 & 1.95 & 0.17 & 0.88 \\
2009 & 2.27 & 0.16 & 0.32 \\
2010 & 2.34 & 0.63 & 0.35 \\
2011 & 1.44 & 0.06 & 0.35 \\
2012 & 2.71 & 0.44 & 0.46 \\
\hline
\end{tabular}

Source: Annual reports of the sample banks

The greater the percentage of ROE, the better efficiency the bank possess as the ratio is composed of profit margin, degree of asset utilization and equity multiplier. The table gives us the data that ROE for SB ranged from 1.95 to $2.71 \%$ over the study period (2008 to 2012). The ROE range for $\mathrm{AB}$ and $\mathrm{JB}$ are $0.17-0.44 \%$ and $0.88-0.46 \%$ respectively. SB bank has increased their ROE by approximately $39 \%$ in the final year from the base year 2008. AB also increased by $158 \%$ but unfortunately JB decreased their ROE by $48 \%$ in the final year of the study period.

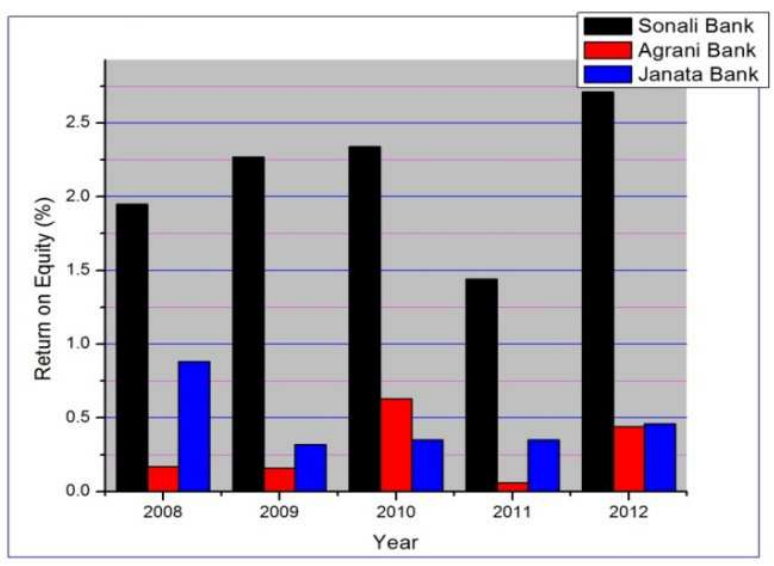

Figure 3. Return on Equity (\%).
The table as well as the figure represents that SB is more efficient in increasing their profit margin, degree of asset utilization and equity multiplier.

\subsection{Return on Risk Asset}

Table 4. Return on Risk Asset.

\begin{tabular}{cccc}
\hline \multirow{2}{*}{ Year } & \multicolumn{3}{c}{ Return on Risk Assets } \\
& Sonali Bank & Agrani Bank & Janata Bank \\
\hline 2008 & - & - & - \\
2009 & .0747 & .0048 & .0095 \\
2010 & .0673 & .0631 & .0085 \\
2011 & .0362 & .0015 & .0079 \\
2012 & .0435 & .0103 & .0088 \\
\hline
\end{tabular}

Source: Annual reports of the sample banks

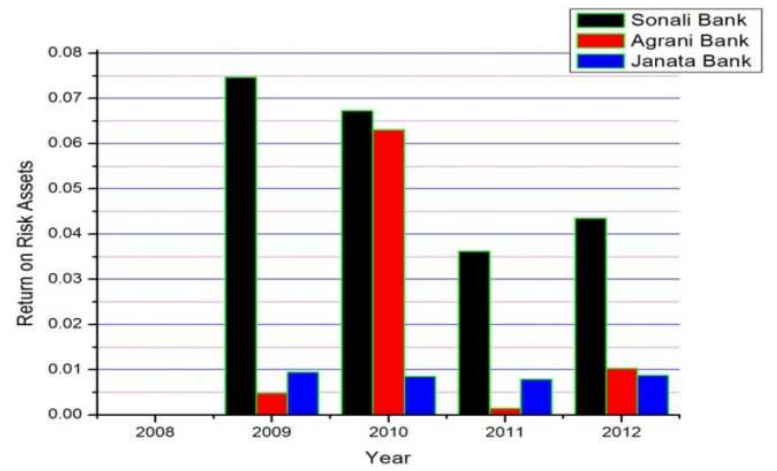

Figure 4. Return on Risk Asset.

In this table, the result of 2008 is not written as the data relating to this ratio was a bit confusing in the annual reports of all the three banks. The data for the rest four years reveals that returns were being fluctuating over the four years. It was comparatively higher for Sonali bank and lower in Janata bank than the other two.

\subsection{Earnings per Share}

Table 5. Earnings per Share (in Taka).

\begin{tabular}{cccc}
\hline Year & Sonali Bank & $\begin{array}{c}\text { Earnings per Share } \\
\text { Agrani Bank }\end{array}$ & Janata Bank \\
\hline 2008 & 3.114 & 0.201 & 1.061 \\
2009 & 3.857 & 0.201 & 0.396 \\
2010 & 4.040 & 0.829 & 0.432 \\
2011 & 2.516 & 0.080 & 0.433 \\
2012 & 4.860 & 0.603 & 0.570 \\
\hline
\end{tabular}

Source: Annual reports of the sample banks

Earnings per share are the potential indicator of the bank's performance in profit earning or, in a nutshell, their efficiency. Here EPS has been calculated based on hundred taka of equity. From table, it is observed that there is an increasing trend in EPS for all the sample banks except JB. The EPS for SB was TK 3.114 in 2008 whereas it was Tk 4.86 in 2012. Therefore it increases $56 \%$ during the study period. The EPS for AB was TK 0.201 in 2008 and it was Tk 0.603 in 2012.Again the EPS for JB was TK 1.061 in 2008 and it was Tk 0.57 in 2012. Therefore it increases for AB and JB $200 \%$ and $46 \%$ respectively. 


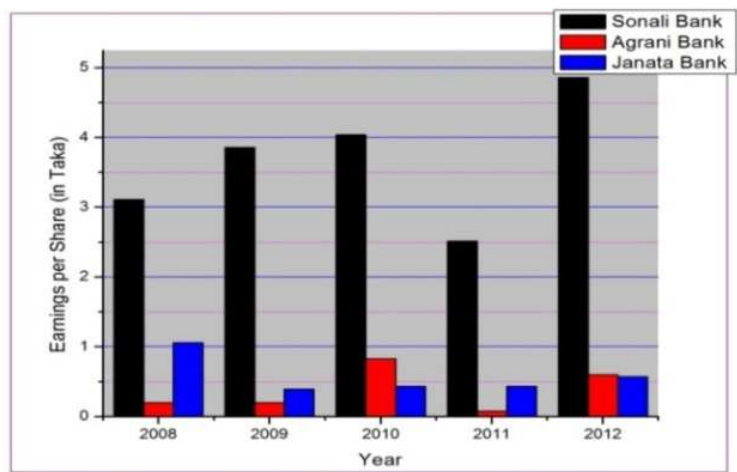

Figure 5. Earnings per Share (in Taka).

The table shows that SB's performance is much better than the other two in increasing their shareholders earnings. The comment can also be supported by figure 5 .

\subsection{Non Interest Income as \% of Total Income}

Table 6. Non Interest Income as \% of Total Income.

\begin{tabular}{cccc}
\hline \multirow{2}{*}{ Year } & \multicolumn{3}{c}{ Non Interest Income as \% of Total Income } \\
& Sonali Bank & Agrani Bank & Janata Bank \\
\hline 2008 & 19.57 & 17.58 & 20.70 \\
2009 & 34.99 & 38.47 & 32.45 \\
2010 & 34.13 & 36.96 & 32.53 \\
2011 & 33.51 & 37.05 & 28.49 \\
2012 & 39.51 & 36.83 & 31.69 \\
\hline
\end{tabular}

Source: Annual reports of the sample banks

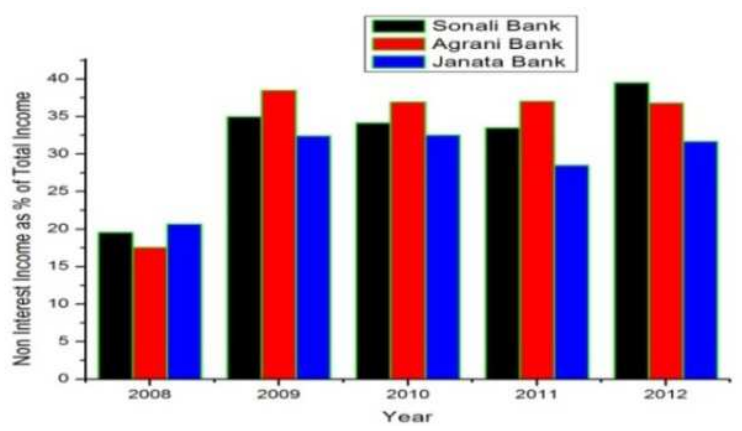

Figure 6. Non Interest Income as \% of Total Income.

Generally we know that, the higher the NII ratio is the lower the credit risks in the part of the bank. Table 6 shows that NII as \% of TI was more or less same over the succeeding four years than the base year (2008). The NII is higher in case of SB than the other two NCBs which reveal that $\mathrm{SB}$ 's noninterest income is higher than $\mathrm{AB}$ and JB.

\subsection{Non Interest Expense as \% of Total Expense}

Table 7. Non Interest Expense as \% of Total Expense.

\begin{tabular}{cccc}
\hline \multirow{2}{*}{ Year } & \multicolumn{3}{c}{ Non Interest Expense as \% of Total Expense } \\
& Sonali Bank & Agrani Bank & Janata Bank \\
\hline 2008 & 26.09 & 25.47 & 28.62 \\
2009 & 26.43 & 24.26 & 28.45 \\
2010 & 23.80 & 23.74 & 29.08 \\
2011 & 22.30 & 22.68 & 28.58 \\
2012 & 22.97 & 23.45 & 28.47 \\
\hline
\end{tabular}

Source: Annual reports of the sample banks

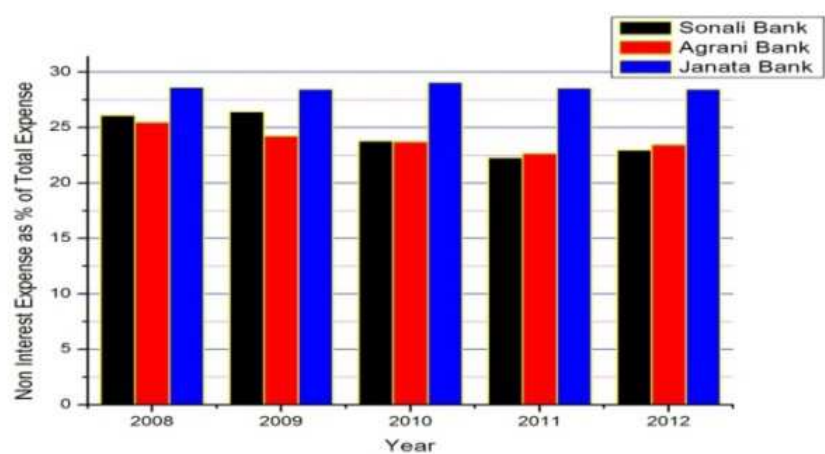

Figure 7. Non Interest Expense as \% of Total Expense.

From table 7 as well as figure 7 we could see that noninterest expense as \% of total expenses is fluctuating over the reference period. For $\mathrm{SB}$ and $\mathrm{AB}$ bank it is in a decreasing trend whereas for $\mathrm{JB}$ it is remained approximately the same. Therefore, we can say that management efficiency in context to $\mathrm{SB}$ and $\mathrm{AB}$ has been increased in the study period.

\subsection{Earning Base in Assets}

Table 8. Earning Base in Assets.

\begin{tabular}{cccc}
\hline & \multicolumn{3}{c}{ Earning Base in Assets } \\
Year & Sonali Bank & Agrani Bank & Janata Bank \\
& .8118 & .8941 & .8620 \\
2008 & .7898 & .9041 & .8567 \\
2010 & .8017 & .8881 & .8419 \\
2011 & .7359 & .8578 & .8373 \\
2012 & .7948 & .8917 & .8383 \\
\hline
\end{tabular}

Source: Annual reports of the sample banks

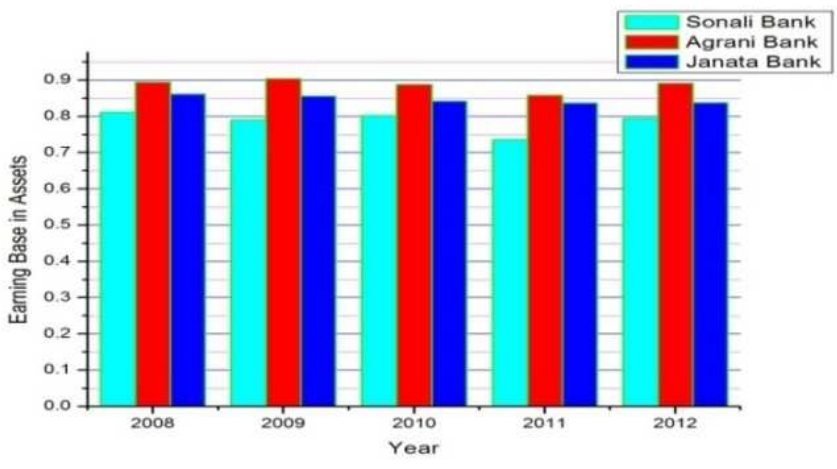

Figure 8. Earning Base in Assets.

Generally, the larger the value of earning base in assets, the more efficient the bank is. The above table shows almost the same as well as higher values for all the three NCBs. But among the NCBs, AB got the better position than SB and JB in relation to earning base in asset. 


\subsection{Deposit-Capital Ratio}

Table 9. Deposit-Capital ratio.

\begin{tabular}{cccc}
\hline Year & \multicolumn{3}{c}{ Deposit-Capital ratio } \\
& Sonali Bank & Agrani Bank & Janata Bank \\
\hline 2008 & 29.11 & 29.52 & 28.38 \\
2009 & 30.56 & 30.08 & 29.86 \\
2010 & 34.98 & 30.91 & 33.40 \\
2011 & 37.77 & 32.08 & 39.80 \\
2012 & 37.94 & 33.91 & 44.03 \\
\hline
\end{tabular}

Source: Annual reports of the sample banks

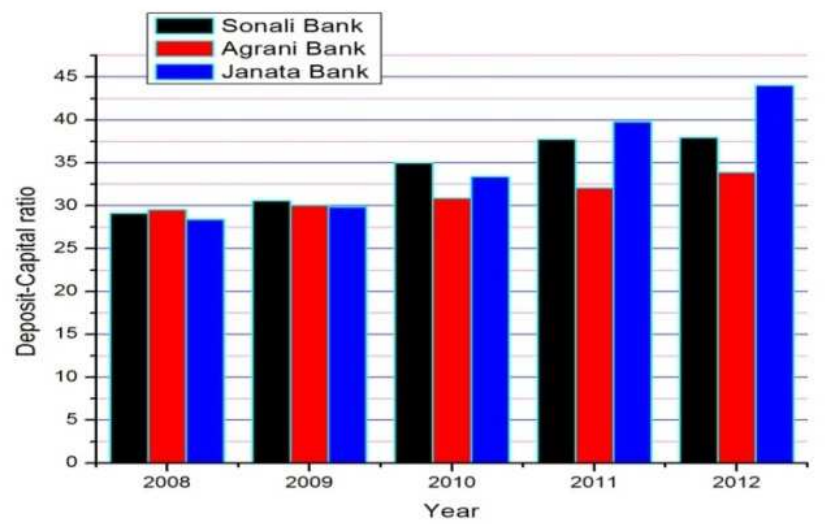

Figure 9. Deposit-Capital ratio.

The greater the deposit-capital ratio, the better performance the bank possesses. Sonali bank and Agrani bank was performing at an average rate throughout the reference period whereas Janata bank was at its peak in 2012 amongst the period. This ratio expresses how much capital is being deployed to deposit mobilization. In the light of the table, it can be said that the banks were performing at an average satisfactory level.

\subsection{Analysis and Findings}

Banks are commercial organizations. The foregoing discussion thus clearly indicates that the performance of NCBs in terms of their contribution to financial development, branch expansion, and deposit mobilization, deployment of credit, profitability and productivity had been characterized by uneven growth pattern, showing virtual absence of systematic and proper planning in their activities. The pace and pattern of NCBs is not indicative of the improvement in the performance. But if we compare among the NCBs from different sides, in some sectors one bank is performing well whereas in other field rest banks are doing well. NCBs are having the larger banking network and are working throughout the country. In context of efficiency and productivity, NCBs are performing with moderate satisfaction in all aspects.

Profitability remains to be the ultimate criterion for the survival of the banks. Prior finding as well as this dissertation tried to reflect the declining profitability of these three nationalized commercial banks, namely Sonali, Agrani and Janata; during the five year period from 2008 to 2012. It is high time to concentrate efforts on improving the profitability and the productivity performance of these banks so that the twin objectives are being fulfilled. The objectives are- (1) the confidence of the general public, who wants to rely on these NCBs, in the soundness of the banking system, remains unimpaired and (2) the financial strength of the banks gets increased. This conclusion chapter tries to pinpoint the major findings and provide some recommendations in the light of analysis of the data.

- $\quad$ Analyzing from the view point of the profitability ratios sample NCBs witnessed the lack of efficiency on the part of utilization of funds in the reference period.

- $\quad$ Net profit in absolute terms was being fluctuated in the reference period for all sample NCBs.

- Interest income constitutes the major portion of the total income which is earned by providing loans. Loans are risky assets on the part of the banks.

- The interest yield ratio of all the banks under the study declined within the reference period that leads to low cushion available for meeting administrative and operating expenses of the banks.

- The banks' ROA shows declining trends. This is because in these years banks' total asset increases as compared to net income.

- Due to fluctuating trend of manpower expenses the overall productivity both per branch and per employee has declined.

- Despite the commendable increase of financial network, there had been a growing concern regarding the operational efficiency (indicated by the profitability and productivity) and level of customer services of the banks.

- Only in the case of deposit mobilization all the sample banks have shown their efficiency. But they lack of mobilizing these funds for want of diversified products to invest.

\section{Conclusion}

\subsection{Conclusion}

The banking sector of Bangladesh has undergone noteworthy financial reforms, which has significantly transformed the sector. At present nationalized commercial banks are dominant in respect of market share and profitability in this sector. Profitability is always an important criterion to measure the performance of banks. This study seeks to examine the determinants of nationalized commercial bank's profitability in Bangladesh by using the data obtained from the financial statements of three the nationalized commercial banks for the year 2008 and 2012.The findings of this study have considerable policy relevance. It could be argued that the more profitable bank will be able to offer more new products and services. To this end, the role of diversified banking activities is particularly important, given that a bank with relatively more innovative ideas and better fund management 
capability may have added advantage over its peers. There are some major findings of the work are, analyzing from the view point of the profitability ratios sample NCBs witnessed the lack of efficiency on the part of utilization of funds in the reference period, net profit in absolute terms was being fluctuated in the reference period for all sample NCBs and Interest income constitutes the major portion of the total income which is earned by providing loans. Loans are risky assets on the part of the banks.

\subsection{Recommendations}

Following suggestions are made to improve the performance of the NCBs:

- The non-interest expense of the commercial banks should be controlled.

- Interest cost should be reduced so that profit of the banks will be increased.

- Efficiency should also be increased through increasing manpower productivity.

- Interest income should be increased through following portfolio investment policy.

- Assets of the banks should be utilized in a very efficient manner to increase the profitability.

\section{References}

[1] "Banks Since Nationalisation". Birla Institute of Scientific Research Allied Publishers Ltd. New Delhi 1981.

[2] Abbasoglu, O. F., Aysan, A. F., Gunes, A. (2007). Concentration, competition, efficiency, and profitability of the Turkish banking sector in the Post-Crisis Period. Banks and Bank Systems, 2 (3): 106-115

[3] Agrani Bank (2008). Annual Report 2007-12. Dhaka: Agrani Bank.
[4] Alpher, D. \& Anbar, A. (2011), Bank Specific and Macroeconomic Determinants of Commercial Bank Profitability: Empirical Evidence from Turkey, Business and Economics Research Journal, Volume 2 . Number 2, pp. 139-152.

[5] Bangladesh Bank (2013). Economic Trends. January. Dhaka: Statistics Department. Bangladesh Bank.

[6] Berger, A. N. (1995). The Relationship between Capital and Earnings in Banking. Journal of Money, Credit and Banking, 27(2), 432-456.

[7] Debnath. R. M. (2013). Bangaleer Bank Baybsa (Bengali). Dhaka. NabajugProkashoni.

[8] Dietrich, A. \&Wanzenried, G. (2009). What Determines the Profitability of Commercial Banks? New Evidence from Switzerland. 12th Conference of the Swiss Society for Financial Market Researches, Geneva. Discussion Paper.

[9] Janata Bank (2008). Annual Report 2007-12. Dhaka: Janata Bank.

[10] Lui, H. \& Wilson, J. (2010). The Profitability of Banks in Japan. Applied Financial Economics, 20(24). pp.1851-1866.

[11] Mishra, Sheila (1992). The Age of the Acheulian in India, Current Anthropology, Vol. 33, No. 3. (Jun., 1992), pp. 325-328.

[12] Naceur, S. B. (2003). The Determinants of the Tunisian Banking Industry Profitability: Panel Evidence. UniversiteLibre de Tunis Working Papers.

[13] Pervan, M., Pervan, I. \&Guadagnino, A. (2010), Market Structure and Profitability of Croatian Commercial Banks, The Business Review, Cambridge, Vol. 16, No. 1.

[14] Sonali Bank, Annual Report 2008-12. Dhaka: Sonali Bank.

[15] Toor, N.S. (1994). Non-Performing Advances in Banks, New Delhi: Skylark Publication. 